Maja Opašić

FILOZOFSKI fakULtet SVEUČILIŠta u RIJECI

RIJEKa, HRVATSKa

mopasic@ffri.hr

https://doi.org/10.17234/9789531755139.22

\title{
ZOONIMSKE SASTAVNICE U BIBLIZMIMA HRVATSKOGA I POJEDINIH JEZIKA ${ }^{1}$
}

\begin{abstract}
U radu se analiziraju biblizmi, odnosno biblijski frazemi i izreke kojima je sastavnicom jedan od sljedećih zoonima: krava, tele, ovca, janje, jarac, svinja, vuk, deva, komarac i zmija. Cilj je rada analizirati značenje i simboliku navedenih zoonima u prikupljenim biblizmima te time dati moguće objašnjenje pozadinske slike pojedinoga biblizma koju motivira ne samo općenita simbolika zoonima nego većim dijelom njegova biblijska uloga. Građa je prikupljena iz različitih jednojezičnih i višejezičnih frazeoloških rječnika, a donose se i primjeri aktualne uporabe pojedinoga hrvatskog biblizma koji su pronađeni u elektroničkim izvorima te mrežnim pretraživačima. U radu se razmatra i status koji prikupljeni biblizmi imaju s obzirom na svoje biblijsko podrijetlo, tj. utvrđuje se pripadaju li izravnim ili neizravnim biblizmima. Hrvatski se zoonimski biblizmi uspoređuju s biblizmima drugih jezika pri čemu se pokazuje njihova veća podudarnost, ali i određene razlike uvjetovane specifičnostima pojedinoga jezika i kulture.
\end{abstract}

Ključne riječi: zoonimska sastavnica, biblizam, frazemska pozadinska slika, hrvatski jezik

\section{Uvod}

Biblija za europske jezike predstavlja najsnažniji izvor različitih leksičkih jedinica kao što su frazemi, uzrečice, kolokacije, poslovice, krilatice i sl. Utjecaj je Biblije na frazeološke sustave tih jezika različit, u kvantitativnim i kvalitativnim, a posebno u semantičko-stilističkim i pragmatičkim odnosima (Chlebda 1997). U hrvatskoj je frazeologiji velik broj jedinica biblijskoga podrijetla, a u ovom se radu analiziraju frazeološki biblizmi hrvatskoga i drugih jezika koji sadrže zoonimsku sastavnicu. Pod pojmom biblizma podrazumijevamo ,lekseme biblijskoga podrijetla te složene jezične jedinice s najmanje jednom desemantiziranom sastavnicom (frazemi, uzrečice, poslovice, izreke i sl.), izrazom i sadržajem potvrđene u Bibliji i/ili izravno ili neizravno povezane $\mathrm{s}$ Biblijom" (Opašić 2013: 65).

Cilj je rada analizirati značenje i simboliku biblijskih zoonima u biblizmima te time dati moguće objašnjenje pozadinske slike pojedinoga biblizma. Pri tome se polazi od pretpostavke da pozadinsku sliku može motivirati ne samo općenita simbolika zoonima nego većim dijelom njegova biblijska uloga. U radu se razmatra i status koji prikupljeni

I Rad je nastao u okviru projekta „Unutarnje posuđivanje u hrvatskome jeziku“ koji financijski podupire Sveučilište u Rijeci. 
biblizmi imaju s obzirom na svoje biblijsko podrijetlo, tj. utvrđuje se pripadaju li izravnim ili neizravnim biblizmima ${ }^{2}$. Taj se status dokazuje navođenjem točnoga biblijskog citata ili opisom konteksta. Hrvatski se zoonimski biblizmi uspoređuju s primjerima iz drugih jezika (engleski, francuski, talijanski, njemački, ruski, poljski, češki) da bi se pokazao njihov status općeeuropeizama.

Građa je prikupljena iz različitih hrvatskih i stranih jednojezičnih i višejezičnih općejezičnih i frazeoloških rječnika navedenih u popisu literature, a donose se i primjeri aktualne uporabe pojedinoga hrvatskog biblizma koji su pronađeni u elektroničkim izvorima te mrežnim pretraživačima.

\section{Simbolika i uloga biblijske zoonimske sastavnice u motivaciji značenja biblizma}

U biblijskome su svijetu Staroga i Novoga zavjeta životinje imale važnu ulogu jer su bile dijelom židovske svakodnevice. Prema M. Crvenku (2013) najvažnija uloga životinja u Bibliji ogleda se u njihovoj podjeli na čiste i nečiste životinje, tj. one koje se smiju jesti i one koje su zabranjene za jelo (Lev 11; Pnz 14,3-21). Tako su primjerice deva i svinja bile nečiste životinje, a ovca, koza, janje, jarac i sl. čiste. Stoga su dobile snažnu simboliku upravo na temelju te uloge pa su nečiste životinje uglavnom negativno obilježene za razliku od čistih kojima se pridaju pozitivna obilježja. „Simbolika pojedine životinje u Bibliji prenesena je i na frazeološki plan pa su tako dominantna obilježja pojedinih zoonima, kao i prispodobe i slike vezane uz njih, motivirale nastanak frazema“" (Ribarova i Vidović Bolt 2005: 644).

\subsection{Biblizmi sa zoonimima ovca, janje i jarac}

Ovca i janje najzastupljenije su životinje u Bibliji koje postaju simbolom nevinosti, pokornosti, blagosti, dobrote čime su motivirani i biblizmi.

Poredbeni frazem kao ovce (stado) bez pastira već u Bibliji opisuje stanje izgubljenosti, bez vodstva, a potvrđen je u sljedećim citatima:

Tada Mihej odgovori: „Sav Izrael vidim rasut po gorama kao stado bez pastira. I Jahve veli: Nemaju više gospodara, neka se u miru kući vrate! " 2 Ljet 18,16

A kad vidje mnoštvo naroda, sažali se nad njim, jer bijahu satrveni i zapušteni kao ovce bez pastira. Mt 9,36-37

Frazemsko značenje nose sastavnice ovca (stado) i pastir. Naime, Izraelci su bili pastirski narod i na stranicama se Biblije često opisuje njihov život, a iz pastirskoga se života uzimaju metafore kojima se želi prenijeti jedna sasvim drugačija poruka

2 Točne izvedenice aforizama ili skupova riječi iz tekstova Biblije u svome završnom obliku mogu se nazvati izravnim biblizmima. Za razliku od njih neizravni su biblizmi jedinice nastale samostalnom kombinacijom biblijskih riječi, slika i sižea koji se ne nalaze u samom tekstu Biblije (Opašić 2013). 
(RBT 1969). Metaforu pastira koji vodi svoje stado upotrebljavaju u drevnoj Mezopotamiji i Egiptu kao naslov za kraljeve pa i Biblija čini isto (npr. 2 Sam 5,2), ali se ona kraljevima i vladarima dodaje uzgred jer su oni pastiri izabrani od Boga (Chevalier i Gheerbrant 2007). Vrlo se rano naslov pastira primjenjuje na Jahvu (usp. Post 48,15), a slika stada i pastira temeljna je biblijska slika za odnos između Boga i Izabranoga naroda (Iz 40,11; Jr 2,8; Ez 23,2; Zah 10,3; Ps 23,1-4). U Novome zavjetu slika pastira i stada dobiva sasvim novo značenje jer postaje metaforom Božje ljubavi prema svim ljudima (stadu), tj. simbolizira samoga Boga. Crkva je novi Izrael, odnosno stado kojemu je pastir Isus Krist, a potom i apostoli (Duda 2008), dok ovca postaje primjerom vjere ili nevjere (Crvenka 2013). Lik Krista pastira dovodi do toga da se i duhovni vođe vjerskih zajednica u suvremenim jezicima nazivaju pastirima ili pastorima.

Navedeni je frazem utemeljen na slici stada koje je bez pastira neorganizirano, nezaštićeno i luta pa je kao takvo metom kradljivaca i divljih zvijeri. Treba napomenuti da je u latinskome tekstu izraz glasio sicut oves absque pastore, a hrvatski su se prevoditelji odlučili prevesti riječju stado u tekstovima Staroga zavjeta, dok su u Novome zavjetu preveli riječju ovce što je podudarno i latinskomu prijevodu. ${ }^{3}$ Stoga su u hrvatskome jeziku moguće i dvije leksičke inačice navedenoga frazema, a u ostalim jezicima samo jedna od inačica, npr. njem. wie Schafe ohne Hirten, rus. как стадо без пастухаa, polj. jak owce bez pasterza.

Hrvatski je frazem uglavnom potvrđen u upotrebi u književnim djelima, npr.

Zar da ih pustim kao stado bez pastira? (HJR)

Zoonim ovca sastavnicom je i biblizma ovce među vukovima. Izraz je potvrđen u sljedećem citatu koji Isus izgovara u trenutku izbora dvanaestorice apostola dajući im različite pouke i savjete za njihovo djelovanje:

Evo, šaljem vas kao ovce među vukove. Zato budite mudri kao zmije, bezazleni kao golubovi! Mt 10,16

Evanđelist Luka $(10,3)$ govori o janjadi među vukovima. Dakle, oba evanđelista apostole uspoređuje sa životinjama kojima Biblija pridaje obilježje neobranjenosti, dok vukovi predstavljaju njihove neprijatelje, ponajprije tadašnje farizejsko vodstvo. Upravo uspoređujući apostole s ovcama i janjadi, Isus ističe njihovu izloženost, ranjivost i bezazlenost (Šaško 2014: 15). Ta se slika može primijeniti na kršćane svih vremena koji će biti prinuđeni živjeti i svjedočiti svoju vjeru u neprijateljskom svijetu (France 1987). Izraz se frazeologizirao u značenju 'slabi među jakima', a potvrđen je u aktualnoj uporabi, npr.

3 Ostali prijevodi imaju i u starozavjetnim tekstovima ovce (engl. as sheep that have no shepherd, njem. wie Schafe, die keinen Hirten haben, tal. come pecore che non hanno pastore, rus. как овец, у которых нет nастыря, polj. jako owce, które nie maja pasterza, češ. jako ovce, kteréźz nemají pastýre), a izdvaja se jedino francuski koji kao i hrvatski ima stado (comme un troupeau qui n'a pas de berger). 
M. P. svojim izlaganjem, (...) istakla je kako se kao članica Sabora koja ne podliježe stranačkom utjecaju već svojoj katoličkoj savjesti osjeća poput ovce koja je poslana među vukove. (http://www.jutarnji.hr, 8. 11. 2012.)

(...) Kad su mi dali otkaz, bila sam ovca među vukovima, ako se vratim, bit ću krvoločni vuk među ovcama. (http://dalje.com, 2. 12. 2012.)

Frazem je potvrđen i u drugim jezicima: engl. a wolf among the sheep, njem. wie Schafe unter Wölfen, franc. loup dans la bergerie, tal. essere un agnello fra i lupi, lupo tra le pecore, rus. оввцы среди волков, волк среди овеu, polj. jak owce pośród wilków. Može se uočiti da je u engleskom, francuskom, talijanskom i ruskom za razliku od hrvatskoga na prvome mjestu u frazemu vuk, a na drugome ovce.

Biblijski motiv izgubljene (zalutale) ovce motivirao je pozadinsku sliku frazema izgubljena (zalutala, zabludjela) ovca (ovčica). Motiv je nastao na temelju pripovijesti o izgubljenoj ovci kao jednoj od triju prispodoba koje donosi evanđelist Luka da bi objasnio ideju o Isusovu milosrđu (RBK 1999). U prispodobi o izgubljenoj ovci (Mt 18,12-14; Lk 15,1-6) Isus se uspoređuje s dobrim pastirom koji ostavlja devedeset i devet ovaca i traži onu izgubljenu te je na svojim ramenima nosi stadu. Naime, ovca je životinja koja živi u stadu i ako zaluta izložena je sigurnoj propasti. Time je želio reći da je došao ne samo zbog pravednika nego još više zbog grešnika koji su zavedeni pogrešnim putovima i krivim prorocima (Limbeck 2009). Važno je istaknuti da evanđelist Matej govori o zalutaloj ovci, a Luka o izgubljenoj pa je hrvatski frazem uključio oba motiva, a opisuje 'osobu koja se odvojila od svoje sredine (društva) i koja je pošla pogrešnim životnim putem’, npr.

Hvala Bogu, da je barem jedna zalutala ovea vidjela, da su - drugi skrenuli s pravoga puta. (HJR)

I čisto se preporodio, kad mu za malo stigne od ravnatelja odgovor, iz kojega je vidio, da se sa raširenim rukama prima kao izgubljena ovca u krilo učitelja (...). (HJR)

Za njih je takav pisac bio i ostao, ako ne izdajnik, ono u najboljem slučaju zabludjela ovca ili heretik. (http://www.pobjeda.me, 16. 11. 2012.)

Frazem se javlja i u drugim jezicima: engl. the lost sheep, njem. das verirrte (verlorene) Schaf, franc. brebis égarée, tal. la pecorella (pecora) smarrita, rus. заблудшая oвu̧a, češ. zbloudilá (bludná, ztracená) ovečka, polj. zbłąkana owca (owieczka).

U Evanđelju po Mateju (25,31-33) govori se o ponovnom Kristovu dolasku kojim će odvojiti vjerne od nevjernih odnosno razlučiti ovce od jaraca:

(...) Tada će se pred njim skupiti svi narodi, a on će ih razlučiti jedne od drugih kao što pastir luči ovce od jaraca. Postavit će ovce sebi s desne strane, a jarce s lijeve. 
Isusova usporedba nastala je na temelju običaja pastira da se odvajaju različite životinje jer su u palestinskim stadima ovce $\mathrm{i}$ jarci često bili izmiješani i na prvi se pogled nije moglo lako razlučiti jedne od drugih s obzirom na to da ovce nisu bile od bijelih europskih vrsta (France 1987). Važno je i to da u Bibliji jarci i koze za razliku od ovaca i janjadi nemaju povlašteni status, tj. nisu izabrane životinje. Zato i u tome tekstu ovce predstavljaju vjernike, a jarci nevjernike. Prema tomu nastao je frazem odvojiti ovce od jaraca koji može značiti 'odvojiti ono što se razlikuje, odvojiti dobro od lošega'. Frazem je samo rječnički zabilježen i nisu pronađeni primjeri u aktualnoj uporabi.

Krotkost u Bibliji podrazumijeva savršenu pokornost Božjoj riječi (BS 2002), a to se obilježje ponajprije pridaje janjetu:

A ja bijah kao jagnje krotko što ga vode na klanje i ne slutih da protiv mene snuju pakosne naume. Jr 11,194

U Starome je zavjetu janje bilo žrtvena životinja i to idealna žrtva (RBK 1999), osobito na blagdan Pashe (Izl 12,21-23). Naime, za žrtvu su se najčešće prinosile ovce i koze, dok se jednogodišnje zdravo muško janje smatralo žrtvom najugodnijom Bogu (PBL 1997). Riječ je o pomirbenoj žrtvi koju treba žrtvovati radi vlastita spasenja (ORL 2002; Chevalier i Gheerbrant 2007), a koja postaje simbolom Isusa Krista koji se žrtvuje za spas ljudi i to upravo na blagdan Pashe. U navedenom se citatu Jahvin sluga uspoređuje s janjetom ili ovcom ne samo zbog svoga tihog i strpljivog podnošenja nepravdi nego kao općenito tumačenje njegove sudbine jer on kao žrtvena životinja nosi grijehe mnogih i polaže svoj život kao žrtvu za krivice (RBT 1969). Stoga se upravo ovaj tekst najčešće povezuje s Isusom Kristom koji postaje novozavjetno pashalno janje (PBL 1997). Na temelju navedenoga biblijskoga motiva janjeta nastali su frazemi pokoran (krotak) kao janje 'jako pokoran, podložan, poslušan', miran kao janje 'jako miran' i žrtveno janje 'nedužna osoba koja mora ispaštati umjesto drugih, žrtva sudbine ili spleta nesretnih okolnosti, onaj koji mora platiti krivnju skupine'. Krotkost janjeta prenijelo se i na ovcu pa se frazemom krotak kao ovca opisuje poslušna osoba (Vidović Bolt 2011).

Do jučer ljuti lav, ili ris, a sada je krotak kao janje i umiljat kao pokorno psetance pred svojim gospodarom... (HJR)

Oni ga mrze, jer ga se boje; meni se pak pričinja krotak kao janje. (HJR)

U ostalim su jezicima potvrđeni posve ili djelomično podudarni primjeri: njem. lammfromm, sanft wie ein Lamm, rus. смирный (кроткий) как ягнёнок (агнеи), с̌еš.

U latinskom (quasi agnus mansuetus) i ruskom prijevodu (как кроткий агнеи) potvrđen je izraz podudaran hrvatskomu, u talijanskome je sličan jer se razlikuje samo pridjevskom sastavnicom (come un docile agnello), dok se ostali prijevodi razlikuju: njemački i sastavnicom ovca umjesto janje (wie ein armes Schaf), engleski i nema pridjevsku sastavnicu nego dodaje i ovna (like a lamb or an ox), dok poljski i češki uspoređuju s janjetom i vukom (polj. jako baranek $i$ wót, češ. jako beránek a volček). 
mírný (krotký) jako beránek (ovečka), polj. cichy (potulny, pokorny) jak jagnię (owca), tagodny jak baranek, tagodny jak jagnie (jagniqtko).

Već je navedeno da janje i ovca u Bibliji imaju snažnu simboliku, a u židovskome poimanju janje ima uz poslušnost $i$,simboličku vrijednost neobranjenosti i ranjivosti“ (Šaško 2014: 14):

Ko ovcu na klanje odvedoše ga, ko janje nijemo pred onim što ga striže on ne otvara svojih usta. Dj 8,32

Motiv žrtvenoga janjeta javlja se već na početku Staroga zavjeta u Knjizi Izlaska kada janje postaje pashalnom životinjom koja se morala jesti u obitelji, a njezinom krvlju morala su se poškropiti vrata. Stoga se u navedenom kao i sljedećim biblijskim citatima misli upravo na takvu žrtvu:

No ti, Jahve, mene poznaješ i vidiš;ispitao si srce moje, ono je s tobom. Odvedi ih kao jagnjad na klanje, sačuvaj ih za dan pokolja. Jr 12,3

Dao si nas k’o ovce na klanje i rasuo nas među neznabošce. Ali zbog tebe ubijaju nas dan za danom, i mi smo im k'o ovce za klanje. Ps 44,12.23

Podcrtani su se izrazi na temelju toga frazeologizirali kao ići kao janje na klanje i voditi koga kao janje (ovce) na klanje, a riječ je o frazemima koji svojim značenjem 'prihvatiti što bez otpora (protesta), ne protiveći se' opisuju prihvaćanje neugodnosti bez pružanja otpora.

No, Dinamo nikada, do jučer, nije išao na utakmice kao janje za klanje. (http:// www.jutarnji.hr, 13. 11. 2012.)

Kao janje na klanje išao je i on ususret svojoj smrti koju su mu pripremili njegovi neprijatelji. (http://www.gospicko-senjska-biskupija.hr, 13. 11. 2012.)

Njegova je krotkost bila u tome što su ga nevina osudili i vodili „k'o krotko janje na klanje“. (http://www.biskupija-sisak.hr, 13. 11. 2012.)

Primjeri iz drugih jezika uglavnom su podudarni: engl. go like a lamb (sheep) to the slaughter, njem. wie ein Lamm zur Schlachtbank gehen, tal. come pecore (portate) al macello, rus. идти как овиа на заклание, с̌eš. jít jako beránek (beran) na popravu, polj. iść jak owca na rzeź.

U pozadinskoj je slici frazema žrtveni (grešni) jarac kao i već spomenutoga žrtveno janje biblijska slika janjeta i jarca kao žrtvenih životinja. Naime, prema Zakoniku u Starome su zavjetu najčešće žrtvene životinje bile jarac i janje, a prinosile su se kao zalog za druge, tj. njihove grijehe odnosno prijestupe. O motivu žrtvovanoga janjeta već je bilo riječi, dok je jarac simbolom rasplodne moći, životne snage i libida te plodnosti, a postaje i slikom pohote (Chevalier i Gheerbrant 2007). U Bibliji je dvolična 
životinja, a osobito divlji jarac. Hebrejska riječ za jarca može značiti i jarac i demon pa je upravo ta neobična veza između jarca i demona možda u začetku svetkovine jarca posvećene Azazelu (BS 2002). Levitski zakonik (16,20-26) opisuje obred pokajanja u kojem Aron, kao glavni svećenik, kockom između dvaju jaraca odabire jednoga koji će biti prinesen Bogu i drugoga koji će se dati Azazelu, zloduhu koji je živio u pustinji. Zato je taj drugi jarac koji se naziva žrtvenim bio otjeran u pustinju da bi okajao grijehe cijeloga naroda. Takav sličan običaj javlja se i kod Egipćana, Grka, Tibetanaca (Walter i Mokienko 2009). Stoga se navedenim frazemima opisuje 'čovjek koji mora ispaštati umjesto drugih, žrtva, onaj koji mora platiti krivnju skupine i biti kažnjen umjesto najčešce pravih krivaca'.

Gradonačelnik je žrtveni jarac predizborne kampanje. (www.slobodnadalmacija. hr, 15. 12. 2012.)

Bila sam žrtveni jarac HDZ-a na predsjedničkim izborima. (www.dnevno.hr, 15. 12. 2012.)

Hoće li se 'žrtveno janje' osvetiti (...) ili će im ostati lojalan i stradati? (www. jutarnji.hr, 15. 11. 2012.)

U drugim su jezicima potvrđeni podudarni primjeri: engl. scapegoat, njem. der Sündenbock sein, franc. boue émissaire, tal. il capro espiatorio, rus. козёл отпущения, polj. koziot ofiarny.

\subsection{Biblizmi sa zoonimima krava i tele}

Za razliku od prethodnih zoonima krava i tele sastavnicom su triju frazema. Sva su tri nastala na temelju vrlo simboličkih biblijskih slika.

Tako su na temelju biblijskog izvještaja iz Knjige Postanka (32,1-24) nastali biblizmi zlatno tele 'novac (zlato, bogatstvo) kao cilj' i klanjati se zlatnome teletu 'imati novac (zlato, bogatstvo) kao ideal i cilj'. Riječ je o događaju kada su Izraelci izradili zlatno tele i počeli mu se klanjati kao božanstvu. Zbog toga su izazvali Božji gnjev, ali i Mojsijev jer je klanjanje i štovanje svetih slika stranih bogova, ali i likova bogova bilo zabranjeno. Zlatno tele tako u Bibliji predstavlja idol, a s obzirom na to da je napravljeno od zlata simbol je materijalnoga bogatstva. Naime, zlato je u Bibliji simbol bogatstva, vrijednosti, autoriteta.

Gotovo je s vremenima kad je »Badel« bio zlatno tele za razne mešetare (...). (HJR)

Slavljenje bogatstva postalo je »klanjanje zlatnom teletu« jer slavi se kao najveće dobro. (http://www.glas-koncila.hr, 16. 11. 2012.)

Hrvatskom imeničkom frazemu zlatno tele potpuno podudarni su: engl. the golden calf, njem. das Goldenes Kalb, tal. vitello d'oro, franc. le veau d'or, rus. золотой телеи, 
češ. zlaté tele, polj. zloty cielec, a hrvatskom glagolskom frazemu klanjati se zlatnome teletu posve podudarni su češ. klanět se zlatému teleti i polj. kłaniać się złotemu cielcowi, dok su mu djelomično podudarni tal. adorare il vitello d'oro i češ. tanec kolem zlatého telete.

Frazem sedam gladnih krava značenja 'zle godine, nerodne, rđave, višegodišnja nerodica' nastao je kao asocijacija na biblijsku priču o Josipu kojega su braća prodala u Egipat gdje se uspio spasiti iz tamnice zahvaljujući sposobnosti tumačenja snova. Naime, faraon je sanjao kako iz Nila izlazi sedam debelih krava koje je proždrlo sedam mršavih krava. Josip mu je taj san protumačio rekavši da debele krave predstavljaju sedam godina blagostanja, a mršave sedam godina gladi (Post 41,1-36). Zahvaljujući takvomu tumačenju, Josip je postao namjesnik i tijekom godina obilja stvorio rezerve žita te time spasio Egipćane od gladi. Važna je u ovome frazemu i simbolika broja sedam koji u Bibliji najčešće simbolizira savršenost ${ }^{5}$.

Primjeri su iz drugih jezika dijelom nepodudarni jer je u najvećem broju jezika (engleski, njemački, francuski, ruski) umjesto sedam krava, sedam godina. Značenjem bi posve podudaran hrvatskome bio poljski siedem krów chudych, a ostali izriču pozitivno i negativno značenje: engl. seven fat years and seven lean years, njem. die sieben fetten und die sieben mageren Jahre, franc. les bonnes et les mauvaises annŭes, tal. le sette vacche grasse e le sette vacche magre; essere il tempo delle vacche grasse, non essere il tempo delle vacche grasse, essere il tempo delle vacche magre, non essere il tempo delle vacche magre; periodo (tempi) di vacche grasse, periodo (tempi) di vacche magre, rus. семь тучных и семь тощих лет, с̌еš. sedm let tučných a sedm (let) hlubených, polj. siedem krów tlustych.

\subsection{Biblizmi sa zoonimom svinja}

Svinja je za Židove bila nečista životinja te postaje simbolom za pokvarenost i grijeh, a Židovima je čuvati svinje bilo najveće poniženje (Crvenka 2013). Stoga ne čudi spominjanje svinja u sljedećem biblijskom kontekstu:

Ne dajte svetinje psima! Ne bacajte svoga biserja pred svinje, da se, pošto ga pogaze, ne okrenu te vas rastrgaju! Mt 7,6

Isus Krist navedenim riječima upozorava svoje učenike da sveti nauk ne treba izlagati ljudima koji ga ne mogu prihvatiti, koji bi ga mogli zloupotrijebiti ili mu se izrugivati (Tomić 1991). Prema navedenom tekstu nastao je biblizam baciti / bacati bisere (biserje) pred svinje (lat. margaritas ante porcos) čije je značenje 'dati / davati (reći / govoriti) što lijepo onomu koji to ne razumije’ stoga ima vrlo šaljivu konotaciju. Za razumijevanje izraza važna je riječ margaritas koja na grčkome može značiti biser, ali i malene dijelove

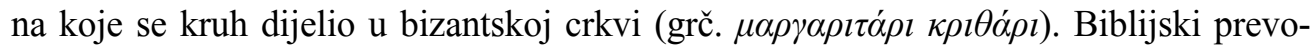
ditelji su riječ margaritas najčešće preveli prema latinskom kao biser ${ }^{6}$, no moguće bi

\footnotetext{
V. više u Macan i Opašić 2010; Opašić 2013.

$6 \quad$ Usp. engl. your pearls before swine, franc. perles devant les pourceaux, njem. Perlen nicht vor die Säие werfen, tal. le vostre perle davanti ai porci, rus. жемчуга вамего перед свиньями, polj. peret waszych przed świnie, češ. mecte perel svých před svině.
} 
značenje bilo upravo da je riječ o komadićima posvećenog kruha pa se svinjama kao nečistim životinjama ne treba dolaziti s čistim, posvećenim kruhom (Walter et al. 2010). U svakome slučaju biseri simboliziraju stvari i riječi koje su svete i nisu razumljive svima.

Oni, naime, nisu dostojni ovog virtuoza jer ih ne interesira kakvu glazbu gudi, već tko je gudi. Opet smo bacali biserje pred svinje! (HJR)

Njegov se istup na konferenciji za novinstvo sveo na onu latinsku: „Ne bacajte biserje pred svinje.“ (HJR)

Primjeri iz drugih jezika posve su podudarni: engl. cast (throw) pearls before swine, njem. Perlen vor die Säue werfen, franc. jetar des perles aux pourceaux (aux cochons), tal. (dare) gettare le perle ai porci, rus. метат бисерь перед свиньями, с̌еš. házet perly sviním, polj. rzucać perty przed świnie.

\subsection{Biblizmi s ostalim zoonimima}

U hrvatskim se biblizmima javlja nekoliko biblijskih divljih životinja: vuk, zmija, deva i komarac.

Dvoličnu osobu sklonu dodvoravanju koja zle (loše) namjere krije pod maskom plemenitosti i blagosti može se opisati biblizmom vuk u ovčjoj (janjećoj) koži (odijelu). Nastao je motiviran slikom koju Isus koristi u citatu iz Matejeva evanđelja $(7,15)$ :

Čuvajte se lažnih proroka što vam dolaze u ovčjem runu, a unutra su grabežljivi vuci!

Isus tim riječima upozorava učenike da se čuvaju lažnih proroka koje vidi kao vukove zamaskirane u ovčjem runu što znači da su takvi proroci vjerojatno dio kršćanske zajednice, predstavljaju se kršćanima i glasnogovornicima Isusa Krista da bi se time približili ljudima (Gnilka 1990). Dakle, suprotstavljena je nevinost i blagost ovce, tj. janjeta sa zlom i pakosti vuka.

Ti vukovi u ovčju kožu se presvlače pred izbore, ali ne treba proći dugo da pokažu svoju pravu ćud. (http://www.lupiga.com, 16. 11. 2012.)

On ga vidi kao vuka u janjećoj koži i naglašava da je upravo njegova administracija zaslužna za proganjanje (...). (http://vecernjilist.newspaperdirect.com, 16. 11. 2012.)

Primjeri iz drugih jezika potvrđuju podudarnost na strukturnoj i semantičkoj razini: engl. a wolf in sheep's clothing, njem. ein Wolf im Schafspelz (Schafskleid), franc. loup déguisé en brebis / loup dans une peau d'agneau (de mouton), tal. il lupo nella pelle dell'agnello, rus. волк в овечьей щккре, češ. vlk v rouchu (rouše) beránčím, polj. wilk w jagnięcej (baraniej) skórze. 
Jedna od najpoznatijih biblijskih poslovica je lakše će deva proći kroz ušicu igle, nego bogataš ući u kraljevstvo Božje koju Isus izgovara govoreći o bogatašima (Mt 19, 23-24; Mk 10,25; Lk 18,25). Ta poslovica izazvala je različita tumačenja, a vjerojatno je riječ o staroj židovskoj i arapskoj poslovici. Neki pretpostavljaju da je utemeljena na sljedećoj slici: u Jeruzalemu je nekada postojao prolaz, tj. niska i uska vrata kroz koja su ulazile životinje, a zvala su se ušica igle. Međutim, deva nije mogla ući u Jeruzalem kroz ta vrata sve dok joj se nije najprije skinuo sav teret koji je nosila, a ona se spustila na koljena. Tim su se vratima služili trgovci i putnici koji su dolazili noću kada su glavna gradska vrata bila zatvorena. Ne postoje ostaci ni materijalni dokazi da su takva vrata postojala pa je ovakvo objašnjenje dijelom neutemeljeno (Cole 1984). Kroz stoljeća pokušavalo se ublažiti Isusovo očigledno preuveličavanje pa dio proučavatelja smatra da je riječ o pogrešci u prepisivanju - umjesto grčke riječi kamelos što znači deva radilo bi se o kamilos što znači debelo uže kojim su se vezali brodovi jer aramenska riječ gamla može značiti i devu i uže (Šaško 2009). Međutim, u babilonskome Talmudu govori se o ljudima koje se smatralo toliko mudrima da su činili naizgled nemoguće i o njima se kaže da provlače „slona kroz iglene uši“. Dakle, Isus je vjerojatno jednostavno upotrijebio tipičnu orijentalnu metaforu da bi kroz snažan kontrast naglasio nemogućnost čega (Cole 1984; Tomić 1991), ali je umjesto slona iskoristio sliku deve kao životinje iz židovske svakodnevice.

Navedenom izrekom Isus nije želio reći da je bogatome nemoguće postići vječni život, pogotovo jer su neki dobrostojeći pojedinci postali njegovi sljedbenici. No, nedugo prije nego je izrekao te riječi, mladi bogataš je odbio ponudu da postane njegovim sljedbenikom jer je više ljubio svoja „mnoga imanja“ (Mt 19,16-22). Za svakog bogataša s takvim stajalištem bilo bi nemoguće naslijediti vječni život.

U hrvatskome jeziku pronađeni primjeri uporabe pokazuju da se najčešće koristi samo prvi dio biblijske izreke prije će deva kroz ušicu igle sa značenjem 'prije će se dogoditi i što nemoguće':

Tvrdnju kako će 'prije najveća deva proći kroz ušicu igle nego će on ući u koaliciju s HDZ-om', pljeskom je pozdravila puna hotelska dvorana (...). (http://www. tportal.hr, 11. 12. 2012.)

Prije deva kroz ušicu igle, nego kapital u Hrvatsku? (http://www.monitor.hr, 11. 12. 2012.)

Pa što nisu pomirili obje strane, u prizemlju crkve sagradit nebesku K-prodavaonicu, a katove udijelit Kaptolu. I obavezno blagoslovit tu trgovačku radnju jer inače će prije deva kroz ušicu igle nego Todo u raj. (http://www.index.hr, 11. 12. 2012.)

Primjeri iz drugih jezika: njem. eher geht ein Kamel durch ein Nadelöhr, tal. è più facile che un cammello passi per la cruna di un ago che un ricco entri nel regno dei cieli, rus. легче верблюду пройти сквозь в игольное ушко, polj. latwiej jest wielbtadowi przejść przez ucho igielne. 
Deva se javlja u još jednom slikovitom biblijskom citatu u kojem je Isus nazvao farizeje slijepim vođama koji cijede komarca, a gutaju devu (Mt 23,24). Bila je to posebno snažna hiperbola jer je bio izrazit kontrast između sićušnog komarca i deve, jedne od najvećih životinja koju su znali Isusovi slušatelji. Procijenjeno je da je potrebno 70 milijuna komaraca da bi po težini bili jednaki devi prosječne veličine. Osim toga, Isus je znao da su farizeji cijedili vino kroz komad tkanine da ne bi progutali komarca i tako postali ceremonijalno nečisti. No, u simboličnom su smislu gutali devu koja je također bila nečista, odnosno nije se smjela jesti (Lev 11,4), ali je smatrana hraniteljicom pustinjskoga naroda (Crvenka 2013). Stoga je Isus tom hiperbolom želio reći da su se farizeji pomno držali i najmanjih i to osobito profanih odredbi Zakona, a zanemarivali su ono važnije, pravdu, milosrđe i vjernost (Mt 23,23) te ih je time razotkrio kakvi su uistinu, licemjerni (Gnilka 1990). Frazem cijediti komarca, a gutati devu već u biblijskom kontekstu ima preneseno značenje koje se može izraziti kao 'biti u neznatnim stvarima savjestan, a u važnima nesavjestan'.

Pozdrav i nemoj mi previše secirati i cijepidlačiti - gutati devu, a cijediti komarca. (www.building-body.com, 13. 11. 2012.)

Sve je to tako jer su ljudi uvijek radi svojih egoističnih ciljeva "cijedili komarca, a gutali devu". (http://hr.linkedin.com, 13. 11. 2012.)

Navedeni biblijski citat motivirao je sasvim sigurno i češki frazem dělat z komára velblouda, no u drugim se jezicima u istom značenju 'preuveličavati što' ustalio frazem latinskoga podrijetla (elephantem ex musca facere), no nije isključen ni biblijski utjecaj: hrv. praviti / napraviti od muhe slona, engl. make a mountain out of a molehill, njem. aus einer Mücke einen Elefanten machen, franc. faire d'une mouche un éléphant, tal. fare d'una mosca un elefante, rus. делашь из мухи слона, с̌еš. dělat z mouchy slona, polj. robić z muchy słonia.

Vrlo lukava, prepredena, ali i mudra čovjeka može se usporediti sa zmijom: lukav (mudar, podmukao) kao zmija. Ta je usporedba nastala parafrazom na temelju biblijskih tekstova u kojima zmija ima snažnu simboličku ulogu. Naime, već izvještaj o istočnome grijehu počinje napomenom: Zmija bijaše lukavija od sve zvjeradi što je stvori Jahve, Bog (Post 3,1). Dakle, zmija je najlukavija jer očito poznaje otrovni učinak zabranjenoga voća te navodeći ženu na grijeh u ljudsko srce ubrizgava otrov neposlušnosti (BS 2002). Zmiju su drevne tradicije smatrale tajnovitim bićem, ali i svetom životinjom povezanom sa životom i mudrošću pa tako ni u Kanaanu zmija nije simbol nesreće. Međutim, ulogom koju joj biblijski pisac daje u prvome grijehu želi pokazati da zmija nije uzvišena nego prokleta životinja pa time osuđuje i kult mnogoboštva u Izraelu (Rebić 1996). Nakon toga postaje simbolom zla i prokletstva i svojevrsnom inkarnacijom đavla (RBK 1999). Motiv zmije javlja se na još nekim mjestima u Starome zavjetu (Izl 4,2-5; Br 21,6-9; Pnz 8,15; Iz 65,25). Isus će u Novome zavjetu zmijama nazvati licemjerne farizeje (Mt 23,33), ali zmiju uzima i kao primjer lukavosti i to ne one zlonamjerne nego krajnje oprezne: 
Evo, ja vas šaljem kao ovce među vukove. Budite dakle mudri kao zmije, a bezazleni kao golubovi! Mt 10,16

Tim riječima želi reći učenicima da kršćani ne moraju biti lakomisleni, ali ni hulje (France 1987). Dakle, prema navedenim biblijskim citatima kao i biblijskoj simbolici zmije mogao je biti motiviran navedeni frazem lukav (mudar, podmukao) kao zmija ('vrlo mudar, lukav, prepreden').

\section{Zaključak}

Semantička analiza biblizama sa zoonimskom sastavnicom pokazala je da se u navedenoj građi izravnim biblizmima mogu smatrati primjeri: kao ovce (stado) bez pastira, ovce među vukovima, ići kao janje na klanje, krotak kao janje, baciti / bacati bisere (biserje) pred svinje, prije će deva kroz ušicu igle, cijediti komarca, a gutati devu. Na temelju biblijskih slika i parabola nastali su neizravni biblizmi sa zoonimskom sastavnicom: $i z$ gubljena (zalutala) ovca (ovčica), žrtveno janje, žrtveni (grešni) jarac, zlatno tele, sedam gladnih krava, vuk u ovčjoj (janjećoj) koži (odijelu), lukav (mudar, podmukao) kao zmija. Može se zaključiti da prevladavaju biblizmi s domaćim životinjama, a najzastupljenije životinje su ovca i janje. Također, analiza je pokazala da je pozadinska slika biblizma motivirana ulogom koju pojedina životinja ima u Bibliji, njezinom simbolikom te biblijskim (kon)tekstom.

Primjeri biblizama iz drugih jezika pokazuju veliku podudarnost koja je i očekivana s obzirom na ulogu koju Biblija ima u kulturi europskih i izvaneuropskih naroda. Stoga biblizmi sa zoonimskom sastavnicom potvrđuju uglavnom status općeeuropeizama, dok su razlike među jezicima uvjetovane specifičnostima pojedinoga jezika i kulture.

\section{LITERATURA}

Chlebda, Wojciech. 1997. Библия в языке - язык в Библии. U: Frazeologia a religia. Lewicki, Andrzej Maria; Chlebda, Wojciech (red.). Problemy frazeologii europejskiej II. Warszawa. 85-94.

Cole, Alan. 1984. Evanđelje po Marku (Uvod i komentar). Novi Sad: Dobra vest.

Crvenka, Mario. 2013. Životinje u Bibliji. Zagreb: Teovizija.

Duda, Bonaventura. 2008. Opći uvod u Bibliju i Uvodi i napomene uz knjige Novoga zavjeta. U: Biblija. Zagreb: Kršćanska sadašnjost. 1379-1388, 1457-1519.

France, R. T. 1987. Matej (Uvod i komentar). Novi Sad: Dobra vest.

Gnilka, Joachim. 1990. Il vangelo di Matteo (parte I, II). Brescia: Paideia.

Macan, Željka; Opašić, Maja. 2010. Frazemi s brojevima sedam i devet u hrvatskome i njemačkome jeziku. U: À la croate - Sbornik vybranych př́spěvkư z konference Setkání mladych kroatistů konané v Brně 13. 4. 2010. Villnow Komárková, Jana (red.). Brno. 101-108.

Limbeck, Meinard. 2009. Matejevo evanđelje. Zagreb: Kršćanska sadašnjost. 
Menac, Antica. 2007. Hrvatska frazeologija. Zagreb: Knjigra.

Opašić, Maja. 2013. Biblizmi u hrvatskome jeziku. Doktorska disertacija. Filozofski fakultet. Sveučilište u Zagrebu. Zagreb.

Rebić, Adalbert. 1996. Stvaranje svijeta i čovjeka (Egzegeza i biblijska teologija Post 1-3 s uvodom u Petoknjižje). Zagreb: Kršćanska sadašnjost.

Ribarova, Slavomira; Vidović Bolt, Ivana. 2005. Biblijski frazemi sa zoonimskom sastavnicom u hrvatskom, češkom i poljskom jeziku. U: Semantika prirodnog jezika i metajezik semantike: zbornik HDPL-a. Granić, Jagoda (red.). Zagreb - Split: Hrvatsko društvo za primijenjenu lingvistiku. 643-654.

Šaško, Ivan. 2009. Bogaćenje ostavljanjem, umnažanje svođenjem na jedno. Živo vrelo. god. XXVI. 10: 26-27.

Šaško, Ivan. Biblijsko-pastirsko-liturgijska simbolika Božjega Jaganjca. Živo vrelo. god. XXXI. 4: $14-19$.

Tomić, Celestin. 1991. Isus iz Nazareta - Prorok i Krist (Isusovo javno djelovanje). Povijest spasenja sv. XI. Zagreb: Provincijalat hrvatskih franjevaca konventualaca.

Vidović Bolt, Ivana. 2011. Životinjski svijet u hrvatskoj i poljskoj frazeologiji I. Zagreb: Hrvatska sveučilišna naklada.

Zagrebačka Biblija. 2008. Zagreb: Kršćanska sadašnjost.

\section{RJEČNICI}

Chevalier, Jean; Gheerbrant, Jean. 2007. Rječnik simbola. Zagreb: Jesenski i Turk.

Cocagnac, Maurice. 2002. Biblijski simboli. Teološki pojmovnik. Zagreb: antiBARBARUS. [BS]

Colin, Didier. 2004. Rječnik simbola, mitova i legendi. Zagreb: Naklada Ljevak.

Fink Arsovski, Željka i dr. 2006. Hrvatsko-slavenski rječnik poredbenih frazema. Zagreb: Knjigra.

Matešić, Josip. 1982. Frazeološki rječnik hrvatskoga ili srpskog jezika. Zagreb: Školska knjiga.

Matešić, Josip et al. 1988. Hrvatsko-njemački frazeološki rječnik. Zagreb - München: Nakladni zavod Matice hrvatske - Verlag Otto Sanger.

Menac, Antica; Fink-Arsovski, Željka; Venturin, Radomir. 2003. Hrvatski frazeološki rječnik. Zagreb: Naklada Ljevak.

Menac, Antica i dr. 2011. Hrvatsko-ruski frazeološki rječnik. Zagreb: Knjigra.

Mikić, Pavao; Škara, Danica. 1992. Kontrastivni rječnik poslovica. Zagreb: August Cesarec Školska knjiga.

Mikić, Pavao; Suzanić, Vjekoslav. 1994. Biblijske poslovice u Hrvata. Zagreb: Školska knjiga.

Opći religijski leksikon. 2002. Rebić, Adalbert (red.). Zagreb: Leksikografski zavod Miroslava Krleže. [ORL]

Praktični biblijski leksikon. 1997. Grabner-Heider, Anton (red.). Zagreb: Kršćanska sadašnjost. [PBL]

Rječnik biblijske kulture. 1999. Fouilloux, Danielle (red.). Zagreb: AGM. [RBK] 
Rječnik biblijske teologije. 1969. Leon Dufour, Xavier (red.). Zagreb: Kršćanska sadašnjost. [RBT]

Vrgoč, Dalibor; Fink Arsovski, Željka. 2008. Hrvatsko-engleski frazeološki rječnik / Croatian-English Dictionary of Idioms. Zagreb: Naklada Ljevak.

Walter, Harry; Mokienko, Valerij M. 2009. Немецко-русский словарь библейской фразеологии (критерии и принщипы составления). Deutsch-Russisches Wörterbuch biblischer Phraseologismen. Mit historisch etymologischen Kommentaren. Universität Greifswald: Ernst-Moritz-Arndt-Universitat Greifswald PhilophischeFakultat.

Walter, Harry et al. 2010. Deutsch-polonisches Wörterbuch biblischer Phraseologismen mit historisch etymologischen Kommentaren. Szczecin - Greifswald: Volumina pl.

\section{MREŽNI IZVORI}

Hrvatska jezična riznica (http://riznica.ihjj.hr/index.hr.htm) [HJR]

Hrvatski nacionalni korpus (www.hnk.ffzg.hr)

Mrežni pretraživač Google (www.google.hr)

Pretraživač biblijskih prijevoda i komentara e-sword (www.e-sword.net)

\section{ZUSAMMENFASSUNG}

\section{ZOONYMISCHE KOMPONENTEN IN DEN BIBLEISMEN DER KROATISCHEN SPRACHE UND EINIGER ANDERER SPRACHEN}

In dieser Arbeit werden biblische Phraseme und Sprichwörter analysiert, die eine der folgenden zoonymischen Komponenten enthalten: Kuh, Kalb, Schaf, Lamm, Bock, Schwein/Sau, Wolf, Kamel, Stechmücke und Schlange. Das Hauptanliegen der Arbeit ist, die Bedeutung und die Symbolik der zoonymischen Komponenten im gesammelten Korpus von Bibleismen zu untersuchen und die phraseologischen Bilder der einzelnen biblischen Phraseme zu erklären: Denn die phraseolgischen Bilder sind nicht nur durch die allgemeine Tiersymbolik motiviert, sondern größtenteils durch ihre biblische Rolle. Das Belegmaterial ist aus verschiedenen einsprachigen und mehrsprachigen Wörterbüchern exzerpiert worden und der praktische Gebrauch dieser Bibleismen wird im nachfolgenden Text anhand von Beispielen aus elektronischen und Internet-Quellen dargestellt. Des Weiteren wird in dieser Arbeit der Status der Phraseme aus dem Korpus in Bezug auf ihre biblische Herkunft festgestellt, d. h. es wird aufgezeigt, ob die Phraseme der Bibel direkt entnommen sind oder der biblischen Quelle frei nachgebildet sind. Die kroatischen zoonymischen biblischen Phraseme werden mit den entsprechenden biblischen Phrasemen in einigen Fremdsprachen verglichen, wobei ihre Konvergenzen zum Vorschein kommen aber auch ihre divergierenden Merkmale, die durch die sprachliche und kulturelle Spezifik der einzelnen Sprache bedingt sind.

Schlüsselwörter: zoonymische Komponente, biblisches Phrasem, phraseologisches Bild, die kroatische Sprache, die Fremdsprachen 